ARTICLE

\title{
Feeding habits of Paralabrax nebulifer (Serranidae) during reproductive and non-reproductive seasons in an adjacent area to Magdalena Bay, Baja California Sur, Mexico
}

Hábitos alimentarios del verdillo Paralabrax nebulifer (Serranidae) durante las temporadas reproductiva y no reproductiva en un área adyacente a Bahía Magdalena, Baja California Sur, México

\section{Julio Alejandro Ysla-Guzmán ${ }^{1}$, Xchel Gabriel Moreno-Sánchez ${ }^{1}$, Martín Oscar Rosales- Velázquez $^{1}$, Víctor Carrasco-Chávez ${ }^{1}$ and José Luis Ortíz-Galindo ${ }^{1 *}$}

'Instituto Politécnico Nacional, Centro Interdisciplinario de Ciencias Marinas (CICIMAR-IPN), Av. Instituto Politécnico Nacional s/n, Col. Playa Palo de Santa Rita, C.P. 23096, La Paz, B.C.S., México

*Corresponding author: jortizgalindo@gmail.com

\begin{abstract}
Resumen.- El verdillo Paralabrax nebulifer es un pez comercialmente importante en la costa occidental de Baja California Sur. Para evaluar la dieta de esta especie y su variación en función del sexo y su condición reproductiva, se capturaron 60 especímenes durante siete muestreos estacionales utilizando trampas de agosto 2016 a agosto 2018 en un área adyacente a Bahía Magdalena, Baja California Sur, México. Se obtuvieron los contenidos estomacales de 50 especímenes (23 machos y 27 hembras). El sexo fue diagnosticado por observación directa de las gónadas. De acuerdo a los índices gonadosomático, hepatosomático y mediante análisis histológico, se corroboró la condición reproductiva del verdillo durante agosto 2016; abril, agosto y septiembre 2017 y agosto 2018; así como la temporada no reproductiva de noviembre 2016 y marzo 2018. El Índice de Importancia Relativa (IRI) se utilizó para clasificar los principales componentes de la dieta, que incluyeron: tres especies de peces, siete especies de crustáceos y una especie de molusco. Según el IRI, la sardina Sardinops sagax y la langostilla Pleuroncodes planipes fueron las presas que más contribuyeron (55\%) a la dieta del verdillo. El análisis ANOSIM mostró que hubo diferencias significativas en la cantidad y tipo de presa consumida por sexo; el análisis SIMPER reveló que la mayoría de las especies que contribuyeron a las diferencias entre sexos, fueron producidas por S. sagax (16,58\%), Euphylax dovii (15,95\%), Stenocionops ovata $(12 \%)$ y $P$. planipes $(11,82 \%)$ para hembras. Hubo diferencias significativas en la cantidad y tipo de presa consumida por tipo de temporada reproductiva; la mayoría de las especies que contribuyeron a las diferencias entre temporadas fueron producidas por Anchoa spp. (27,76\%) y P. planipes (22,67\%) para la temporada no reproductiva, y por S. sagax $(11,08 \%)$ para la temporada reproductiva. La estrategia de alimentación del verdillo fue la de un depredador carnívoro especialista, que durante la temporada reproductiva se alimenta principalmente de los peces Sardinops sagax, que cubren los requerimientos nutricionales dietéticos de los lípidos AGAI (ácido araquidónico, 20:4n-6; ácido eicosapentaenoico, 20:5n-3; ácido docosahexaenoico 22:6n-3), nutrientes necesarios para lograr el éxito reproductivo.
\end{abstract}

Palabras clave: Estacionalidad reproductiva, ecología alimentaria, Clupeidae, Galatheidae

Abstract.- The barred sand bass Paralabrax nebulifer is a commercially important fish off the west coast of Baja California Sur. To assess the diet of this species and variations as a function of sex and reproductive condition, 60 specimens were captured using traps during seven seasonal sampling trips from August 2016 to August 2018 in an adjacent area to Magdalena Bay, Baja California Sur, Mexico. The stomach contents of 50 specimens were obtained ( 23 males and 27 females). Sex was diagnosed by direct observation of the gonads. Based on the gonadosomatic index, hepatosomatic index, and histological analyses, the reproductive season of the barred sand bass was corroborated for August 2016, April, August, and September 2017, and August 2018, and the non-reproductive season was corroborated for November 2016 and March 2018. The Index of Relative Importance (IRI) was used to classify the main diet components, which comprised three fish species, seven crustacean species, and one mollusk species. According to the IRI, the South American pilchard Sardinops sagax and the red pelagic crab Pleuroncodes planipes were the prey that contributed the most $(55 \%)$ to the barred sand bass diet. The ANOSIM showed that there were significant differences in the amount and type of prey consumed by sex; the SIMPER analysis revealed that the species contributing the most to differences between the sexes were $S$. sagax (16.58\%), Euphylax dovii (15.95\%), Stenocionops ovata (12\%), and P. planipes (11.82\%) for females. There were significant differences in the amount and type of prey consumed between types of reproductive season; the species contributing the most to differences between seasons were Anchoa spp. (27.76\%), and P. planipes for non-reproductive season (22.67\%), and S. sagax (11.08\%) for reproductive season. The feeding strategy of the barred sand bass was that of a specialist carnivorous predator that fed mainly on the fish Sardinops sagax during the reproductive season, which supply the dietary nutritional requirements of the lipids HUFA (arachidonic acid, 20:4n-6; eicosapentaenoic acid, 20:5n-3; docosahexaenoic acid, 22:6n-3), nutrients required to achieve reproductive success.

Key words: Reproductive seasonality, feeding ecology, Clupeidae, Galatheidae 


\section{INTRODUCTION}

Changes in the amplitude and phasing (i.e., phenology) of seasonally varying processes can significantly affect the functioning of marine ecosystems, from primary producers to fish stocks (Beare \& McKenzie 1999, Bograd et al. 2002). In particular, at mid- to high trophic levels, the phenology of upwelling may be linked to match and mismatch between productivity and the life cycles of predators and prey (Ward et al. 2006, Durant et al. 2007). These types of oceanographic phenomena occur in the coastal zone of Magdalena Bay (Zaytsev et al. 2003).

In fish, reproductive success must be strictly adapted to seasonal events in the environment, whether such fluctuations are the result of cyclical seasonal variations or migrations during the natural life cycle of some species. In those with seasonal reproduction, an important adaptation refers to the spawning time, which is adjusted in such a way that the specific feeding needs of the larvae coincide with the seasonal availability of food (Yamahira 2004, Jalabert 2005).

Seasonal, ontogenetic, and reproductive variations in the diet have been recorded in various species of serranids (Ferry et al. 1997, Mendoza-Carranza \& Rosales-Casián 2000, Nakai et al. 2001, Bocanegra-Castillo et al. 2002, Freitas et al. 2015, Vasiliki 2016, Rachedi et al. 2018), but none addresses the relationship of reproductive seasonality and diet composition associated with changes in the oceanic environment. On the other hand, data on the ecobiology of each species of interest in its natural environment may be very useful in creating adequate culture conditions, leading to reproductive maturation and spawning (Mylonas et al. 2010).

The barred sand bass Paralabrax nebulifer (Girard, 1854) belongs to the family Serranidae. Its distribution ranges from Santa Cruz, California (USA), to Magdalena Bay, Baja California Sur, Mexico, including Guadalupe Island (Miller \& Lea 1972), where it is captured at depths between 30 and $185 \mathrm{~m}$ (Smith-Vaniz et al. 2010, Robertson \& Allen 2015). In a study off the California coast, Love et al. (1996) found that $P$. nebulifer spawns from April to August, with a peak in July and that it tends to form large reproductive aggregations on sandy bottoms during its reproductive season. They estimated that $50 \%$ of females mature at 23.9 $\mathrm{cm} \mathrm{TL}$ at 2 to 5 years of age, while $50 \%$ of males mature at $21.9 \mathrm{~cm}$ TL at 2 to 4 years of age. The barred sand bass migrates seasonally to the coast during its reproductive season, returning towards rocky bottoms during the nonreproductive season (Jarvis et al. 2010, Smith-Vaniz et al. 2010). The barred sand bass is an important species of high economic value in Mexico, with catches oscillating between 4,000 and 6,000 tons per year. This species is captured yearround, with peaks in catches between March and August in the state of Baja California Sur (SAGARPA 2016), where fishermen take advantage of their reproductive migration to the coast. In a study on reproductive aggregations, Erisman et al. (2017) found that in Punta Abreojos, Baja California Sur, local commercial fisheries do not increase their catch during the months of spawning activity (July and August). In the Gulf of Ulloa on the western coast of Baja California Sur, where $91 \%$ of the state fishing resource is captured (SAGARPA 2016), the commercial capture of this species has been affected by the creation of a fishing refuge (published by the Mexican government in June 2016; DOF $2016^{1}$ ), which was justified by the interaction with marine turtles. This refuge was extended for five more years in June 2018 (DOF 2018 ${ }^{2}$ ). For this reason, it is necessary to obtain bio-ecological information that contributes to $P$. nebulifer fisheries management plan (DOF 20213).

Despite its economic importance in the state of Baja California Sur, there are no studies on how diet influences on reproductive seasonality of this species. The objective of the present study was to characterize the diet composition of the barred sand bass in an area adjacent to Magdalena Bay, Baja California Sur, during its reproductive and nonreproductive seasons. This will allow us to approximate the nutritional requirements of this species, so that in the future an inert food can be designed to achieve reproduction in captivity and contribute to fisheries management plan.

${ }^{1}$ DOF. 2016. Acuerdo por el que establece la zona de refugio pesquero y nuevas medidas para reducir la posible interacción de la pesca con tortugas marinas en la costa occidental de Baja California Sur. Diario Oficial de la Federación, México, 23 de junio, 14 pp.

${ }^{2}$ DOF. 2018. Acuerdo por el que se amplía la vigencia del similar por el que se establece la zona de refugio pesquero y nuevas medidas para reducir la posible interacción de la pesca con tortugas marinas en la costa occidental de Baja California Sur. Diario Oficial de la Federación, México, 25 de junio, $2 \mathrm{pp}$.

${ }^{3}$ DOF. 2021. Acuerdo por el que se da a conocer el plan de manejo pesquero de verdillo (Paralabrax nebulifer Girard 1854) en la Península de Baja California. Diario Oficial de la Federación, México, 1 de marzo, 31 pp. 


\section{MATERIALS AND METHODS}

\section{STUdY AREA}

All samples were collected with help from artisanal fishermen in August and November 2016; April, August, and September 2017; and March and August 2018, using wire mesh traps with $5 \mathrm{~cm}$ mesh width (Erisman et al. 2017). Fishing occurred exclusively in the daytime (08:00 to 13:00 h). One fisherman deployed two traps in the morning at two different sites and retrieved those $40 \mathrm{~min}$ later, and repeated this procedure as long as weather conditions allowed. Each trap was placed at an approximately $50 \mathrm{~m}$ depth in an adjacent area to Magdalena Bay, Baja California Sur, Mexico (Fig. 1). The sea surface temperature values of the sampling sites were obtained from the satellite image consulted of NOAA's CoastWatch ${ }^{4}$ website, provided by the Aqua satellite of the MODIS sensor, with a resolution of $500 \mathrm{~m}$.

\section{SAMPLING}

The barred sand bass specimens were identified (Fischer et al. 1995b), transported to shore alive, and sacrificed with an overdose of anesthetic ( $40 \mathrm{mg} \mathrm{L}^{-1}$ clove oil). The total length (TL, $\pm 0.5 \mathrm{~mm}$ ), standard length (SL, $\pm 0.5 \mathrm{~mm}$ ), and weight $(\mathrm{W}, \pm 1 \mathrm{~g})$ of each specimen were recorded. Sex was identified macroscopically: females were identified based on the appearance of the ovaries and the presence of oocytes, and males were identified based on large and firm testes and milt released with gentle pressure on the abdomen (BrownPeterson et al. 2011. A portion of the gonad (approximately one cubic centimeter) was also preserved with Davidson fixative. The stomachs were extracted by cutting from the esophagus to the pylorus; stomachs were frozen and transported to the laboratory for analysis.

\section{REPRODUCTION}

To corroborate the reproductive or non-reproductive condition of fish collected in the wild, at least five samples were obtained from each of the catches when possible, and gonad samples were processed histologically. The samples were dehydrated and embedded in paraffin, and 3-mm transverse sections were stained with hematoxylineosin (Humason 1979). The histological preparations were analyzed under a microscope and photographs were taken with a digital camera (CoolSNAP-Pro, Media Cybernetics) coupled to an optical microscope (Olympus ${ }^{\circledR}$ BX41). The histological features used to assign the reproductive phases of female and male gonads were based on Brown-Peterson et al. (2011); the most abundant types of oocytes and the presence and abundance of germ cells were considered.

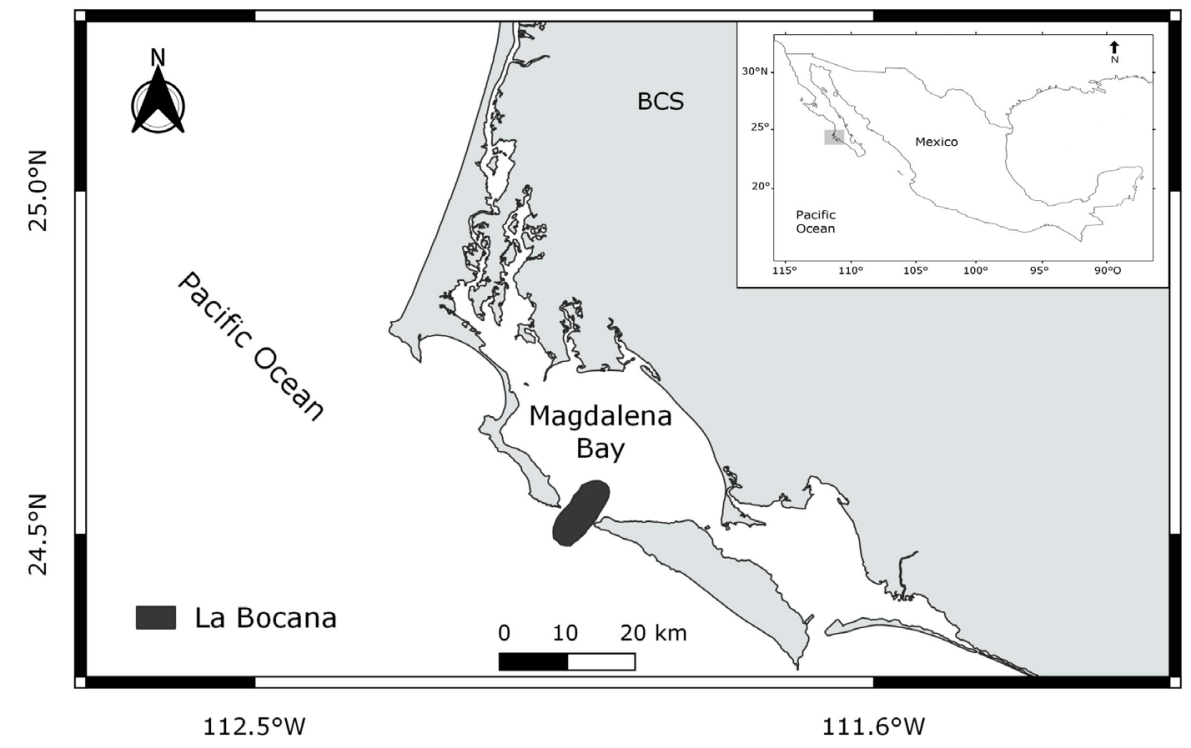

Figure 1. Study area. The dark ellipse indicates the area where barred sand bass Paralabrax nebulifer were caught, an adjacent area to Magdalena Bay, Baja California Sur, Mexico / Área de estudio. La elipse oscura indica el área de captura del verdillo Paralabrax nebulifer en un área adyacente a Bahía Magdalena, Baja California Sur, México

${ }^{4}<$ http: //coastwatch.pfeg.noaa.gov> 
The reproductive season was determined through the temporal variation of the frequency of the stages of gonadal maturity, the histological analysis, and the seasonal variation of the gonadosomatic index, hepatosomatic index, and Fulton's condition factor (García-Díaz et al. 1997).

For each individual, the gonadosomatic index (GSI) was calculated as:

$$
G S I=W \text { gonad } / W \text { fish } \times 100
$$

The hepatosomatic index (HSI) was calculated as:

$$
H S I=W \text { liver } / W \text { fish } \times 100
$$

and Fulton's condition factor $(\mathrm{K})$ was calculated as:

$$
K=W \text { fish } / L P^{3}
$$

where $W$ gonad is the gonad weight (g), $W$ liver is the liver weight (g), W fish is the fish body weight (g), and $L P^{3}$ is the standard length $\left(\mathrm{mm}^{3}\right)$.

The mean GSI, HIS, and K were calculated for each seasonal sampling during the study period.

The sex ratio was evaluated with a Chi-square test at a $95 \%$ significance level based on the proportion of males and females.

\section{DIET}

In the laboratory, prey was counted, weighed, and identified to the lowest possible taxonomic level using specialized identification keys (Miller \& Lea 1972, Brusca 1980, Wolff 1984, Fischer et al. 1995a, b). Data were grouped by sex (male or female) and season (reproductive or non-reproductive). The bait (Sardinops sagax) was differentiated from consumed prey because the bait did not appear complete but in pieces, as it had been previously crushed.

The quantitative analysis of diet was based on the frequency of occurrence $(\% \mathrm{~F})$, number $(\% \mathrm{~N})$, and weight $(\% \mathrm{~W})$ indices (Hyslop 1980), which were used to calculate the IRI proposed by Pinkas et al. (1971) and modified by Hacunda (1981):

$$
I R I=(\% N+\% W) * \% F
$$

This index is expressed as a percentage (Cortés 1999) and indicates the importance of each prey item in the predator's diet:

$$
\%_{0} I R I_{i}=\left(100 I R I_{i} / \sum_{i=1}^{n} I R I_{I}\right)
$$

Diet width was calculated with Levin's standardized index (Hurlbert 1978), based on the absolute number of each prey item. If the index is close to zero it indicates a specialist feeding strategy, and if it is close to one it indicates a generalist strategy (Krebs 1999):

$$
B_{i}=\frac{1}{n-1}\left(\frac{1}{\sum_{j} p_{i j}^{2}}-1\right)
$$

where $B i$ is the niche Breadth, $\sum p^{2} j$ is the proportion of the $j$ item in predator $i$ 's diet, and $n$ is the total number of prey items.

An analysis of similarities (one-way ANOSIM, with 999 permutations) was performed to test for differences in diet according to sex and reproductive season (Clarke 1993). The resulting $\mathrm{R}$ statistic $(-1<\mathrm{R}<1)$ describes the similarity between groups defined according to the above factors. Values close to zero indicate no difference, and values close to 1 or -1 indicate a significant separation between groups. $P$-values were considered significant when $P<0.05$. (Clarke \& Gorley 2006). Following the ANOSIM global test, post-hoc tests were done using a Similarity Percentage analysis (SIMPER) (Clarke \& Warwick 1994), which identified which prey types were the most responsible for significant differences found between samples (data of each sex or reproductive season).

Costello's analysis (Costello 1990) modified by Amundsen et al. (1996) was used to interpret the feeding strategy of the barred sand bass and to assess population and individual patterns. The trophic level was calculated based on the number of prey in stomach contents, using the equation proposed by Cortés (1999):

$$
T L_{k}=1+\left(\sum_{j=1}^{11} p_{j} * T L_{j}\right)
$$

where $T L_{j}$ is the trophic level of each prey category $j$, and $p_{j}$ is the proportion of each prey category in the diet. The trophic level of each prey category was based on Cortés (1999) and López-García et al. (2012).

\section{RESULTS}

\section{GENERAL BIOLOGICAL PARAMETERS AND REPRODUCTION}

The total length shown as mean \pm standard error (and range) of Paralabrax nebulifer specimens was $30.1 \pm 3.4$ (29.2-31.0) cm and weight was 377.6 \pm 127.9 (345.3-410.0) $\mathrm{g}$ (Table 1). The sex ratio (F:M) was 1.17:1 (Chi-square: $\chi^{2}=$ $0.102 ; \mathrm{fd}=1$ ), which is not significantly different from $1: 1$. 
According to the histological analyses, in August 2016, the female gonad was at a very advanced vitellogenesis, since it was even possible to observe the migration of the germinal vesicle, which corresponds to the developing phase (Fig. 2A); whereas the variety and diversity of the spermatic cells of the male gonad corresponded to the developing phase (Fig. 2B). In November 2016, the female gonad contained early and late perinucleolar cells, which corresponds to the immature phase (Fig. 2C); in the case of males, some spermatic sinuses with sperm were observed, as well as two melanomacrophage centers characteristic of the regenerating phase (Fig. 2D). In April 2017, the female gonad was observed with oocytes in the cortical alveolus stage, which characterizes the developing phase (Fig. 2E); while in males the presence of purple spermatozoa (Sz) was observed, evidence that the gonad was in the developing phase (Fig. 2F).
Table 1. Mean and standard deviation of weight (W), total length (TL), and standard length (SL) of specimens collected during seven sampling trips in an adjacent area to Magdalena Bay, Baja California Sur. RS1, RS2, RS3A, RS3B, and RS4: reproductive seasons; NRS1 and NRS2: non-reproductive seasons / Promedio y desviación estándar del peso (W), la longitud total (LT) y la longitud patrón (LP) de los ejemplares muestreados en las siete capturas realizadas, en un área adyacente a Bahía Magdalena, Baja California Sur. TR1, TR2, TR3A, TR3B y TR4 temporadas reproductivas; TNR1 y TNR2, temporadas no reproductivas

\begin{tabular}{ccclcc}
\hline Capture & n & Season & \multicolumn{1}{c}{ W (g) } & TL (cm) & SL (cm) \\
\hline Aug (2016) & 16 & RS1 & $438.5 \pm 229.3$ & $30.6 \pm 6.5$ & $25.1 \pm 4.5$ \\
Nov (2016) & 3 & NRS1 & $260.7 \pm 87.6$ & $27.3 \pm 3.1$ & $23.3 \pm 3.3$ \\
Apr (2017) & 6 & RS2 & $384.3 \pm 152.1$ & $30.2 \pm 3.8$ & $25.1 \pm 3.1$ \\
Aug (2017) & 10 & RS3A & $352.9 \pm 72.7$ & $29.9 \pm 2.1$ & $24.9 \pm 1.8$ \\
Sept (2017) & 12 & RS3B & $376.8 \pm 105.1$ & $30.0 \pm 2.9$ & $25.9 \pm 2.3$ \\
Mar (2018) & 9 & NRS2 & $413.2 \pm 146.2$ & $31.8 \pm 3.4$ & $26.7 \pm 3.6$ \\
Aug (2018) & 4 & RS4 & $417.0 \pm 102.0$ & $30.9 \pm 2.2$ & $26.0 \pm 2.4$ \\
\hline
\end{tabular}

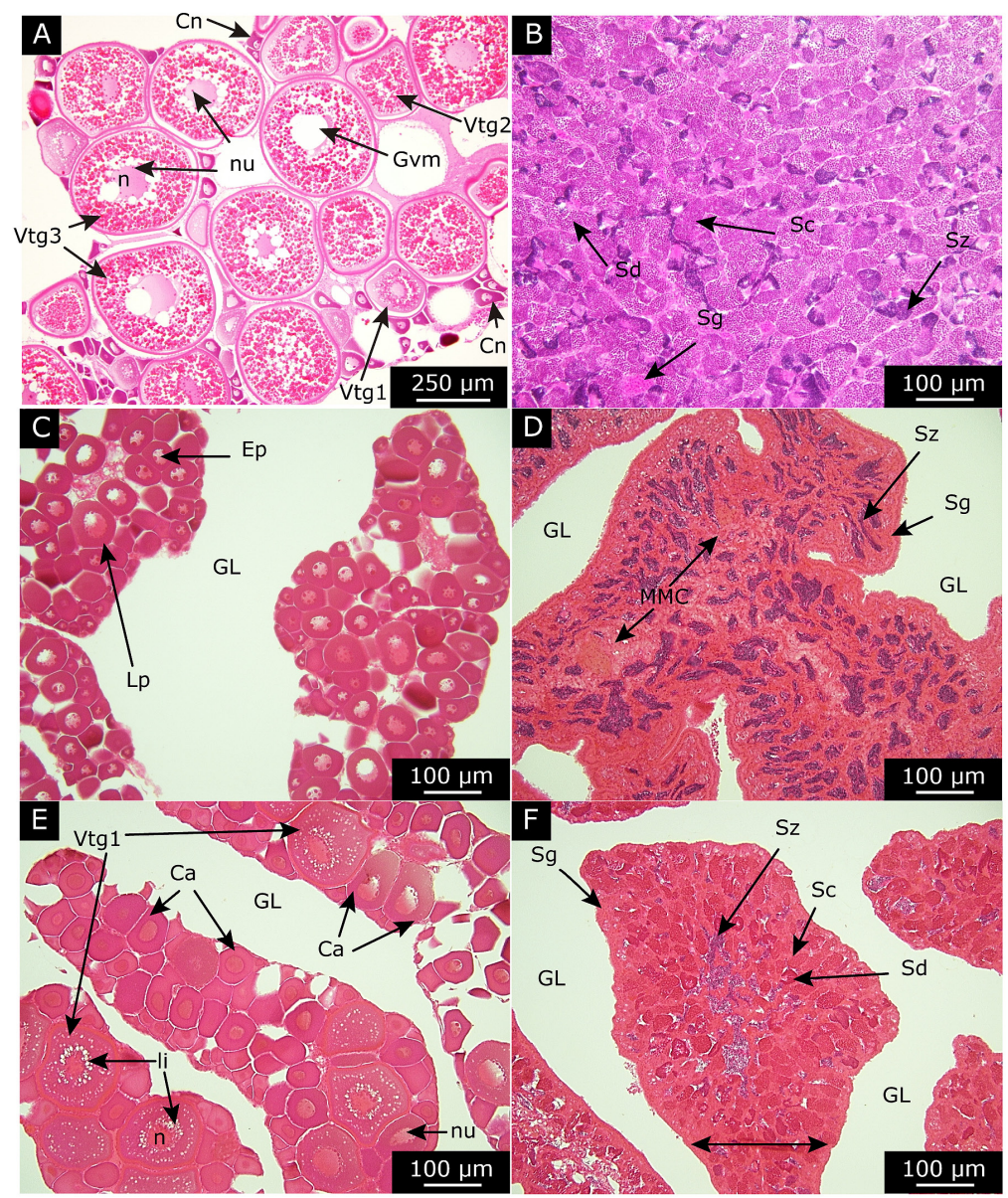

Figure 2. Reproductive phases of the gonads of female (left side) and male (right side) specimens of Paralabrax nebulifer off an adjacent area to Magdalena Bay, Baja California Sur, Mexico. H \& E staining. Developing phase (A-B) (August 2016); regenerating (C) and regressing (D) (November 2016); developing (E-F) (April 2017). Nucleolus (nu), nucleus (n), lipid inclusions (li), chromatin nucleolus (Cn), early perinucleolus (Ep), late perinucleolus (Lp), cortical alveolus (Ca), vitellogenesis 1 (Vtg1), vitellogenesis 2 (Vtg2), vitellogenesis 3 (Vtg3), germ vesicle migration (Gvm), spermatogonia (Sg), spermatocyte (Sc), spermatid (Sd), spermatozoa (Sz), lamella (L), gonadal lumen (GL), and melano-macrophage center (MMC) / Fases reproductivas de las gónadas de los ejemplares hembras (lado izquierdo) y machos (lado derecho) de Paralabrax nebulifer de un área adyacente a Bahía Magdalena, Baja California Sur, México. Tinción con H y E. Fase en desarrollo (A-B) (agosto 2016); regeneración (C) y regresión (D) (noviembre 2016); desarrollo (E-F) (abril 2017). Nucléolo (nu), núcleo (n), inclusiones lipídicas (li), nucléolo cromatina (Cn), perinucléolo temprano (Ep), perinucléolo tardío (Lp), alvéolo cortical (Ca), vitelogénesis 1 (Vtg1), vitelogénesis 2 (Vtg2), vitelogénesis 3 (Vtg3), migración de la vesícula germinal (Gvm), espermatogonia (Sg), espermatocisto (Sc), espermátide (Sd), espermatozoide (Sz), lamela (L) lumen gonadal (GL), centro melanomacrófago (MMC) 
In August 2017, oocytes at an advanced stage of vitellogenesis ( $\mathrm{Vtg} 3$ ) were observed in the female gonad, which characterizes the spawning capable phase (Fig. 3A); in males the gonad had well-defined sperm tubules (ST) and sperm, characteristic of the spawning capable phase (Fig. 3B). In September 2017, in the female gonad, postovulatory follicles (Pof) were observed in the stroma and cells at the nucleolus chromatin stage $(\mathrm{N})$ were abundant, which indicates the end of the spawning period, however, mature oocytes were observed in the rest of the section, so it was characterized as the spawning capable phase (Fig. 3C); the male gonads showed residual spermatozoa, to the extent that their own seminiferous tubules had lost their shape due to the large amount of sperm inside them; this was considered the spawning capable phase (Fig. 3D).
In March 2018, showed a female gonad with a postovulatory follicle (Pof), in which a strong predominance of immature cells was evident, but not a single one was at the cortical alveolus stage, which indicates that the female gonad corresponded to the regenerating phase (Fig. $3 \mathrm{E})$; the male gonad showed the presence of completely immature sex cells, as well as the presence of wellpigmented melanomacrophage centers, corresponding to the regenerating phase (Fig. 3F).

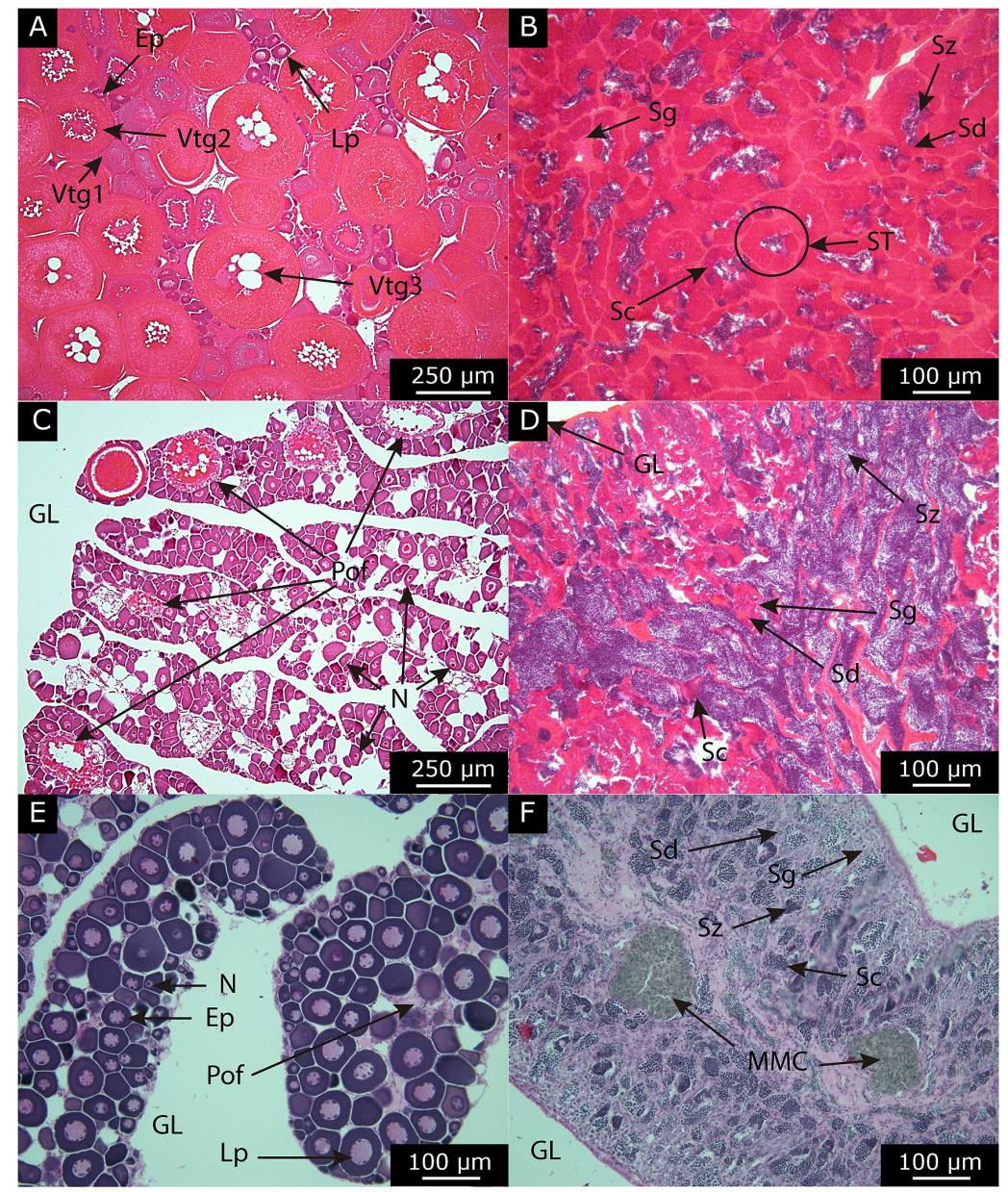

Figure 3. Reproductive phases of the gonads of female (left side) and male (right side) specimens of Paralabrax nebulifer off an adjacent area to Magdalena Bay, Baja California Sur, Mexico. Spawning capable (A-B) (August 2017); regressing (C-D) (September 2017); regenerating (E-F) (March 2018). Early perinucleolus (Ep), late perinucleolus (LP), vitellogenesis 1 (Vtg1), vitellogenesis 2 (Vtg2), vitellogenesis 3 (Vtg3), postovulatory follicle (Pof), spermatogonia (Sg), spermatid (Sd), spermatocyte (Sc), spermatozoa (Sz), gonadal lumen (GL), melanomacrophage center (MMC), and seminiferous tubule (ST) / Fases reproductivas de las gónadas de los ejemplares hembras (lado izquierdo) y machos (lado derecho) de Paralabrax nebulifer de un área adyacente a Bahía Magdalena, Baja California Sur, México. Capacidad de desove (A-B) (agosto 2017); regresión (C-D) (septiembre 2017); regeneración (E-F) (marzo 2018). Nucléolo cromatina (Cn), perinucléolo temprano (Ep), perinucléolo tardío (Lp), vitelogénesis 1 (Vtg1), vitelogénesis 2 (Vtg2), vitelogénesis $3(\mathrm{Vtg} 3$ ), folículo postovulatorio (Pof), espermatogonia (Sg), espermatocisto (Sc), espermátide (Sd), espermatozoide $(\mathrm{Sz})$, lumen gonadal $(\mathrm{GL})$, centro melanomacrófago (MMC), túbulo seminífero (ST) 
The sea surface temperature (SST), gonadosomatic index (GSI), hepatosomatic index (HIS), and Fulton's Condition Factor (K) are shown in Table 2. The highest SST were found in August/September (2017), and August (2018). The highest GSI were found in August (2016), April/August (2017), and August (2018). The highest HIS were found in August/November (2016) and April (2017). The $\mathrm{K}$ values remained high during most of the seasonal samplings, with the exception of April (2017).

Histological results and the gonadosomatic index, hepatosomatic index, Fulton's condition factor, and sea surface temperature suggest that the reproductive season occurs between April and September.

\section{DIET}

Three fish species, seven crustacean species, and one mollusk species were identified. A total of 75 prey organisms weighing $256.73 \mathrm{~g}$ were counted. The prey with greatest number and weight were the fish Sardinops sagax $(16 \% N, 35.9 \% W)$, the red pelagic crab Pleuroncodes planipes $(14.7 \% N, 15.2 \% W)$, and the fish Anchoa spp. $(14.7 \% N, 6.8 \% W)$. According to the \%IRI, the prey with greatest relative importance in the diet were the fish $S$. sagax $(35.9 \%)$, the crustacean P. planipes (18.9\%), and the fish Anchoa spp. (13.6\%), as well as the crustaceans Stenocionops ovata (11.9\%), Euphylax dovii (9.7\%), and Penaeus californiensis (4.9\%). These preys represented $95 \%$ of the IRI as a whole (Table 3 and Fig. 4).
Table 2. Mean and standard deviation of the sea surface temperature (SST), the gonadasomatic index (GSI), the hepatosomatic index (HSI), and Fulton's Condition Factor (K) of specimens collected during seven sampling trips in an adjacent area to Magdalena Bay, Baja California Sur, Mexico. RS1, RS2, RS3A, RS3B, and RS4: reproductive seasons; NRS1 and NRS2: non-reproductive seasons / Promedio y desviación estándar de la temperatura superficial del mar (TSM), del índice gonado-somático (IGS), el índice hepato-somático (IHS) y el factor de condición de Fulton (K) de los ejemplares muestreados en las siete capturas realizadas, en un área adyacente a Bahía Magdalena, Baja California Sur, México. TR1, TR2, TR3A, TR3B y TR4 temporadas reproductivas; TNR1 y TNR2, temporadas no reproductivas

\begin{tabular}{ccccccc}
\hline Capture & n & SST & GSI & HSI & K & Season \\
\hline Aug (2016) & 16 & $23.7 \pm 0.6$ & $3.8 \pm 1.3$ & $30.6 \pm 6.5$ & $1.5 \pm 0.7$ & RS1 \\
Nov (2016) & 3 & $23.5 \pm 0.3$ & $0.5 \pm 0.2$ & $27.3 \pm 3.1$ & $1.2 \pm 0.0$ & NRS1 \\
Apr (2017) & 6 & $17.7 \pm 1.0$ & $1.1 \pm 0.4$ & $30.2 \pm 3.8$ & $0.8 \pm 0.1$ & RS2 \\
Aug (2017) & 10 & $24.6 \pm 0.6$ & $3.9 \pm 1.6$ & $1.7 \pm 0.5$ & $1.3 \pm 0.1$ & RS3A \\
Sept (2017) & 12 & $25.2 \pm 0.4$ & undetermined & undetermined & $1.3 \pm 0.1$ & RS3B \\
Mar (2018) & 9 & $18.0 \pm 0.5$ & $0.5 \pm 0.3$ & $1.4 \pm 0.4$ & $1.3 \pm 0.3$ & NRS2 \\
Aug (2018) & 4 & $24.2 \pm 0.6$ & $1.2 \pm 0.9$ & $1.3 \pm 0.1$ & $1.4 \pm 0.1$ & RS4 \\
\hline
\end{tabular}

Nine prey types were identified in the stomachs of the 23 barred sand bass males. The \%IRI indicated that the most important prey were the fish $S$. sagax (41.4\%), the crustacean E. dovii (24.3\%), and the fish Anchoa spp. (13.0\%). Eleven prey types were identified in the stomachs of the 27 barred sand bass females; the most important were the crustacean P. planipes (44.6\%), the fish $S$. sagax (21.7\%), and the crustacean S. ovata (14.2\%) (Fig. 4).

Table 3. Prey groups in the diet composition of the barred sand bass Paralabrax nebulifer off an adjacent area to Magdalena Bay, Baja California Sur, Mexico. Absolute and percent values of the index of relative importance (\%IRI) are given by $\mathbf{W}=$ weight, $\mathrm{N}=$ number, $\mathrm{F}=\mathrm{frequency}, \mathrm{TL}=$ trophic level / Grupos de peces en la composición de la dieta del verdillo Paralabrax nebulifer de un área adyacente a Bahía Magdalena, Baja California Sur, México. Los valores absolutos y porcentuales del índice de importancia relativa (\% IIR) están dados por $\mathrm{W}=$ peso, $\mathrm{N}=$ número, $\mathrm{F}=$ frecuencia, $\mathrm{TL}=$ nivel trófico

\begin{tabular}{|c|c|c|c|c|c|c|c|c|c|}
\hline \multirow{2}{*}{ Prey } & \multicolumn{8}{|c|}{$\%$ IRI } & \multirow{2}{*}{$\mathrm{TL}$} \\
\hline & W & $\% \mathrm{~W}$ & $\mathrm{~N}$ & $\% \mathrm{~N}$ & $\mathrm{~F}$ & $\% \mathrm{~F}$ & IRI & \%IRI & \\
\hline \multicolumn{10}{|l|}{ Malacostraca } \\
\hline Pleuroncodes planipes & 39 & 15.2 & 11 & 14.7 & 11 & 22.0 & 656.9 & 18.9 & 2.5 \\
\hline Euphylax dovii & 20 & 7.8 & 10 & 13.3 & 8 & 16.0 & 338.0 & 9.7 & 2.5 \\
\hline Stenocionops ovata & 49 & 19.1 & 7 & 9.3 & 7 & 14.0 & 397.9 & 11.5 & 2.5 \\
\hline Calappa convexa & 1.1 & 0.4 & 1 & 1.3 & 1 & 2.0 & 3.5 & 0.1 & 2.5 \\
\hline Petrochirus californiensis & 20.2 & 7.9 & 4 & 5.3 & 2 & 4.0 & 52.8 & 1.5 & 2.5 \\
\hline Penaeus californiensis & 4.0 & 1.6 & 8 & 10.7 & 7 & 14.0 & 171.1 & 4.9 & 2.5 \\
\hline Hepatus lineatus & 1.8 & 0.7 & 2 & 2.7 & 2 & 4.0 & 13.5 & 0.4 & 2.5 \\
\hline \multicolumn{10}{|l|}{ Cephalopoda } \\
\hline Lolliguncula spp. & 1.33 & 0.5 & 6 & 8.0 & 4 & 8.0 & 68.1 & 2.0 & 3.2 \\
\hline \multicolumn{10}{|l|}{ Actinoprerygii } \\
\hline Sardinops sagax & 92.1 & 35.9 & 12 & 16.0 & 12 & 24.0 & 1245.0 & 35.9 & 3.2 \\
\hline Anchoa spp. & 17.4 & 6.8 & 11 & 14.7 & 11 & 22.0 & 471.8 & 13.6 & 3.2 \\
\hline Caranx spp. & 10.8 & 4.2 & 3 & 4.0 & 3 & 6.0 & 49.2 & 1.4 & 3.7 \\
\hline Total & 256.73 & 100 & 75 & 100 & 50 & & 3467.8 & 100 & \\
\hline
\end{tabular}




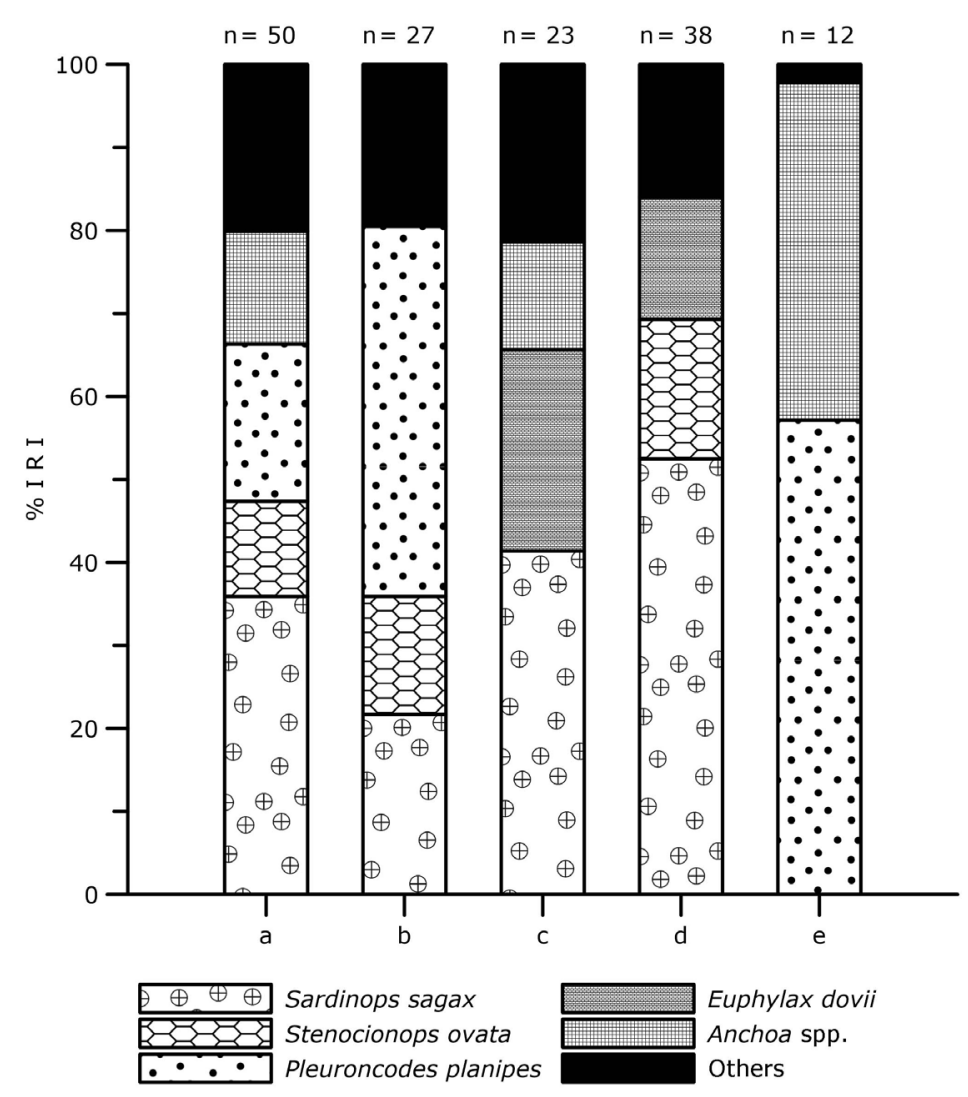

Figure 4. Prey species consumed by Paralabrax nebulifer determined by the index of relative importance (\%IRI). (a) General diet, (b) Females, (c) Males, (d) reproductive season, and (e) non-reproductive season. Prey comprising $80 \%$ of the $P$. nebulifer diet are included. The number of samples taken for each item was written on each column / Especies presa consumidas por Paralabrax nebulifer determinadas mediante el índice de importancia relativa (\%IIR). (a) Dieta general, (b) Hembras, (c) Machos, (d) temporada reproductiva y (e) temporada no reproductiva. Se consideraron las presas que constituyeron el $80 \%$ de la dieta de $P$. nebulifer. El número de ejemplares tomados de cada rubro mencionado, fue escrito sobre cada columna

There were statistically significant differences between the sexes (Chi-square: $\chi^{2}=19.28, \mathrm{fd}=10$ ).

A total of 38 barred sand bass stomachs $(76 \%)$ were analyzed during the reproductive season and the prey that contributed most to the diet, according to the \%IRI, were the fish $S$. sagax $(52.5 \%)$ and the crustaceans $S$. ovata $(16.8 \%)$ and E. dovii (14.7\%). A total of 12 stomachs (24\%) were analyzed during the non-reproductive season and the most important prey, according to the \%IRI, were the crustacean P. planipes (57.1\%) and the fish Anchoa spp. (40.7\%) (Fig. 4).

There were significant differences between the sexes (ANOSIM, $\mathrm{R}=0.024 ; P=0.01$ ). The SIMPER analysis showed that most of the differences between the sexes (56.36\%) were produced by S. sagax (16.58\%), Euphylax dovii (15.95\%), Stenocionops ovata (12\%), and P. planipes $(11.82 \%)$ for females. There were significant differences between the seasons (ANOSIM, $\mathrm{R}=0.113 ; P$ $=0.01)$. The SIMPER analysis showed that most of the differences between the seasons (61.51\%) were produced by Anchoa spp. (27.76\%), and P. planipes (22.67\%) for non-reproductive season, and S. sagax (11.08\%) for reproductive season. No significant interactions were found between the sexes and the reproductive season (ANOSIM, $\mathrm{R}=0.031 ; P=0.13$ ).

The feeding strategy of the barred sand bass was that of a specialist predator $\left(B_{i}=0.38\right)$. This behavior was seen in males $\left(B_{i}=0.35\right)$ and females $\left(B_{i}=0.26\right)$, as well as during the reproductive season $\left(B_{i}=0.20\right)$, whereas during the nonreproductive season $\left(B_{i}=0.52\right)$ the barred sand bass tended to be a generalist predator. The Costello graph modified by Amundsen et al. (1996) showed that the barred sand bass consumed few preys, and that the abundance and frequency of those prey were similar in the diet, so that there was not a dominant prey (Fig. 5a). Males fed mainly on S. sagax, E. dovii, and Anchoa spp., whereas females fed mainly on $P$. planipes, S. sagax, S. ovata, and Anchoa spp. (Fig. 5b, c). The most important prey during the reproductive season were $S$. sagax, S. ovata, and E. dovii, whereas the most important prey during the non-reproductive season were P. planipes, Anchoa spp., and P. californiensis (Fig. 5d, e). The trophic level of the barred sand bass was 3.8; it was 3.9 for males and 3.8 for females; 3.8 during the reproductive season, and 3.9 during the non-reproductive season. 


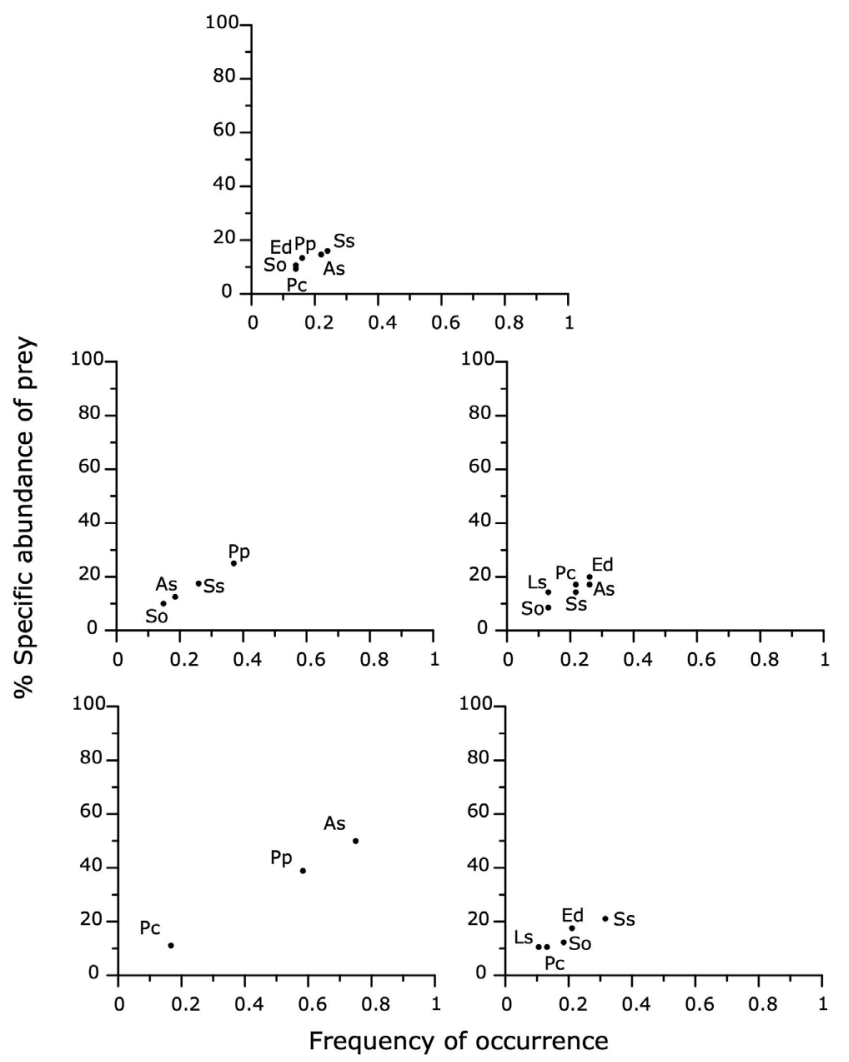

Figure 5. Graph of the feeding strategy obtained using Costello's method. Prey-specific abundance (\%N) and percent frequency of occurrence (\%F) in the Paralabrax nebulifer diet. General diet (a), males (b), females (c), reproductive season (d), and non-reproductive season (e). Pp, Pleuroncodes planipes; Ed, Euphylax dovii; So, Stenocionops ovata; Pc, Penaeus californiensis; Ss, Sardinops sagax; and As, Anchoa spp. / Gráfica de la estrategia alimentaria obtenida con el método de Costello. Abundancia presa-especifica (\%N) y porcentaje de frecuencia de ocurrencia (\%F) en la dieta de Paralabrax nebulifer. De acuerdo a dieta general (a), machos (b), hembras (c), temporada reproductiva (d) y (e) temporada no reproductiva

\section{DiscuSSION}

The size of the $P$. nebulifer specimens captured during the present study corresponded to adult specimens, according to the size at first maturation recorded for the California coast (Love et al. 1996; Baca-Hovey et al. 2002), due to the selectivity of the fishing gear used.

According to results obtained using the gonadosomatic index, hepatosomatic index, Fulton's condition factor, and macroscopic and histological analyses of the gonads, the reproductive season occurred in August 2016, April, August and September 2017, and August 2018; according to the SST, these months can be characterized as the warm season. The non-reproductive season occurred in November 2016 and March 2018, characterized as the cool season. According to the developmental phases of the gonads, the highest reproductive activity (spawning capable phase) was observed in the warm season and particularly in the month of August 2017. During this reproductive seasonality, also reported from California to Punta Abreojos (Jarvis et al. 2010, Erisman et al. 2017), P. nebulifer migrate from offshore waters to more productive near-shore habitats and spawn at short intervals for a period of two to three months. This same situation was reported for Sciaenops ocellatus in the Western Atlantic (Fuiman \& Faulk 2013).

According to the results of the diet composition, barred sand bass are carnivores that fed mainly on fish (Sardinops sagax and Anchoa spp.) and crustaceans (Pleuroncodes planipes and Stenocionops ovata) in an adjacent area to Magdalena Bay. This contrasts with the study by Roberts et al. (1984) in California, where the main prey were brachyuran crabs, mysids, pelecypods, and epibenthic fish, and with the study by Mendoza-Carranza \& RosalesCasián (2002) in Baja California, who reported gammarid amphipods (50.91\%IRI) and fish (16.28\%IRI) as the main prey. This feeding pattern shows that the barred sand bass is a predator that can feed on prey on the benthos as well as in the water column, which places this species as a euryphagous carnivore (Smith 1989). It is important to note that fish and invertebrate species consumed by specimens in this study were not the same as those reported in previous studies and that the proportion of each prey was different. This could be due to characteristics of the study location; Magdalena Bay can be considered the southern boundary of the transition zone between the subarctic and subtropical waters of the northeastern Pacific Ocean, with 
marked seasonality (Zaytsev et al. 2014), which acts as an ecological barrier for several species (Brusca \& Wallerstein 1979, Parrish et al. 1981, Norton et al. 1985). Therefore, these oceanographic boundaries could explain differences found in the prey consumed by barred sand bass in its most southern location, compared with the rest of its distribution.

Despite differences in prey consumed by barred sand bass in different geographic locations, it should be noted that fish are important in the diet (up to $50 \%$ of diet). This has been confirmed by Roberts et al. (1984), who reported that off southern California, large barred sand bass were mainly piscivores, whereas small specimens preferred crustaceans (Brachyura) and pelecypods, and other organisms associated with the benthos. Serranids in general show high trophic diversity (Gómez et al. 1999), which suggests that the barred sand bass is able to adapt according to the food availability in its distribution area.

There were significant differences by sex, as males fed mainly on fish (54\%) and on a lower proportion of crustaceans (24\%), whereas females showed the opposite pattern ( $21 \%$ fish and $68 \%$ crustaceans). This could suggest that there is resource partitioning between the sexes as a function of habitat.

Seasonal variations in diet were also found, with high consumption of fish (S. sagax $52.5 \%$ IRI) and of the crustaceans S. ovata (16.8\%IRI) and E. dovii (14.7\%IRI) during the reproductive season, and consumption mainly of the crustacean red pelagic crab during the non-reproductive season (P. planipes, $57.1 \%$ IRI). In a study by MendozaCarranza \& Rosales-Casián (2002), seasonal variations in the diet of the barred sand bass were observed; the species fed mainly on fish and gammarids in the summer (46.2 \%IRI, $40.0 \%$ IRI, respectively), while in winter gammarids became the preferred diet ( $88.4 \%$ IRI) and the proportion of fish consumed was reduced (5.1\%IRI). A similar result was found in the congeneric species spotted sand bass Paralabrax maculatofasciatus in Bahia de Los Angeles, Baja California, in the Gulf of California (Ferry et al. 1997), where crustaceans were the preferred prey during the spring (cool season) and fish remains, ophiuroids, and brachyuran crabs were the main food components during the fall (warm season). These results contrast with what were reported by Mendoza-Carranza \& Rosales-Casián (2000) for the spotted sand bass on the Pacific coast in Punta Banda Estuary, Baja California and Ojo de Liebre Lagoon, Baja California Sur (Bocanegra-Castillo et al. 2002), where crustaceans were the most important prey during summer (warm season). In Punta Banda Estuary fishes and decapod crustaceans were the preferred prey in winter (cool season), whereas Callinectes bellicosus and fish, gammarids, and mollusks were the most important food components in November (cool season) in Ojo de Liebre Lagoon.
These similarities and differences in the diet that occur between serranid species or even in the same species in different locations can be explained by prey availability during each season and by the opportunistic behavior of the predator. The prey obtained in the present study showed high \%IRI values of S. sagax in the warm season (reproductive season) and $P$. planipes in the cool season (non-reproductive season), which is when this prey reproduce and reach their greatest abundances (AuriolesGamboa et al. 1994, Torres-Villegas et al. 2007).

In the Magdalena Bay zone, during warm season when $P$. nebulifer undertake their reproductive migration towards the coastal zone, the coastal upwelling events increases off April to June (Zaitsev et al. 2003) and causes the match and mismatch between the reproductive process and the opportunity of the predators to have new prey at their disposal to obtain adequate nutrition for the reproductive process (Yamahira 2004, Ward et al. 2006, Durant et al. 2007). According to McKinzie (2014), the barred sand bass population is associated with different substrates depending on the reproductive condition. During the reproductive season, their migration is associated with sandy bottoms and carries out large movements in the water column, a situation that favors the capture of fish, while during the non-reproductive season it is associated with sandy-reef bottoms, so that it coincides with the abundance of the benthic resource Pleuroncodes planipes.

Thus, it was found that during this season the main food was the sardine Sardinops sagax, a small pelagic fish that presents its highest reproductive peak during winter (Torres-Villegas et al. 2007); according to evidence obtained in other eastern boundary systems, for small pelagic fishes as sardines the warm season corresponds to their so-called "feeding season", characterized by lipid storage (Silva et al. 2006), which in turn are transferred to predatory fish (Fuiman \& Faulk 2013). One of the main contributions of stored lipids are the supply of the dietary nutritional requirements of lipids HUFA (arachidonic acid, 20:4n-6; eicosapentaenoic acid, 20:5n-3; docosahexaenoic acid, 22:6n-3), nutrients required to achieve reproductive success, which are important for fertility, hatching rate, and larval survival (Fernández-Palacios et al. 1995, Cardona et al. 2015). The prey $P$. planipes, consumed mainly during the non-reproductive season, are rich in carotenoids, particularly astaxanthin, which serves as a source of antioxidants that protect the lipids HUFA (Torrisen \& Christiansen 1995), that are stored during the feeding season. Regarding diet variations during the reproductive process, the feeding pattern of barred sand bass is similar to what was reported for the serranid Cephalopholis urodeta in a study carried out in southern Japan, where fish $(50 \% \mathrm{~W})$ were abundant in the diet of mature fish, and the proportion of Galatheidae consumed was higher in February than during the other months (Nakai et al. 2001). 
The trophic level found for barred sand bass in this study was 3.8 , which places it as a tertiary consumer (Cortés 1999) feeding on prey at the second level of the trophic chain, such as crustaceans (P. planipes, Penaeus californiensis, S. ovata) and teleosts (S. sagax and Anchoa spp.). This is similar to what has been reported for Serranus cabrilla (3.9, Rachedi et al. 2018) and Serranus scriba (3.8, Vasiliki 2016). According to the food group table reported by Vasiliki (2016), trophic level values between 3.7 and 4.0 obtained with TROPH correspond to carnivores with a preference for decapods. The other species in the genus would be considered carnivores with a preference for fish, with trophic level values between 4.0 and 4.5 (Vasiliki 2016), P. maculatofasciatus (4.2) and Paralabrax auroguttatus (4.2) (Aurioles-Gamboa et al. 2013).

In conclusion, the barred sand bass is a third-order opportunistic carnivore with the feeding strategy of a specialist that preys on species forming aggregations in the pelagic and benthic zone of Magdalena Bay, and that fed mainly on the fish Sardinops sagax during the reproductive season, which warranting the nutritional contribution of the lipids HUFA, nutrients required to achieve reproductive success.

\section{ACKNOWLEDGMENTS}

The authors thank the Consejo Nacional de Ciencia y Tecnología (CONACyT) for economic support provided and the Instituto Politécnico Nacional for BEIFI, EDI, and COFFA scholarships. The graphic material was custom tailored by Armando Hernández López.

\section{LITERATURE CITED}

Amundsen PA, HM Gabler \& FJ Staldvik. 1996. A new approach to graphical analysis of feeding strategy from stomach contents data-modification of the Costello (1990) method. Journal of Fish Biology 48: 607-614.

Aurioles-Gamboa D, MI Castro-González \& R PérezFlores. 1994. Annual mass strandings of pelagic red crabs, Pleuroncodes planipes (Crustacea: Anomura: Galatheidae), in Bahia Magdalena, Baja California Sur, Mexico. Fishery Bulletin 92(2): 464-470.

Aurioles-Gamboa D, M Rodríguez-Pérez, L SánchezVelasco \& M Lavín. 2013. Habitat, trophic level, and residence of marine mammals in the Gulf of California assessed by stable isotope analysis. Marine Ecology Progress Series 488: 275-290.

Baca-Hovey C, LG Allen \& TE Hovey. 2002. The reproductive pattern of barred sand bass (Paralabrax nebulifer) from southern California. California Cooperative Oceanic Fisheries Investigations Report 43: 174-181.

Beare DJ \& E McKenzie. 1999. Connecting ecological and physical time-series: the potential role of changing seasonality. Marine Ecology Progress Series 178: 307-309.
Bocanegra-Castillo N, LA Abitia-Cárdenas, VH CruzEscalona, F Galván-Magaña \& L Campos-Dávila. 2002. Food habits of the spotted sand bass Paralabrax maculatofasciatus (Steindachner 1868) from Laguna Ojo de Liebre, B.C.S., México. Bulletin of the Southern California Academy of Sciences 101(1): 13-23.

Bograd SJ, I Shroeder, N Sarkar, X Qiu, WJ Sydemann \& FB Schwing. 2009. Phenology of coastal upwelling in the California Current. Geophysical Research Letters 36: L01602. <doi: 10.1029/2008GL035933>

Brown-Peterson NJ, DM Wyanski, F Saborido-Rey, BJ Macewickz \& K Lowere-Barbieri. 2011. A standardized terminology for describing reproductive development in fishes. Marine and Coastal Fisheries 3(1): 52-70.

Brusca RC. 1980. Common intertidal invertebrates of the Gulf of California, 513 pp. The University of Arizona Press, Tucson.

Brusca RC \& BR Wallerstein. 1979. Zoogeographic patterns of idoteid isopods in the northeast Pacific, with a review of shallow water zoogeography of the area. Bulletin of the Biological Society of Washington 3: 67-105.

Cortés E. 1999. Standardized diet compositions and trophic levels of sharks. ICES Journal of Marine Sciences 56(5): 707-717.

Costello MJ. 1990. Predator feeding strategy and prey importance: a new graphical analysis. Journal of Fish Biology 36(2): 261-263.

Durant JM, DØ Hjermann, G Ottersen \& NC Stenseth. 2007. Climate and the match or mismatch between predator requirements and resource availability. Climate Research 33: 271-283.

Erisman BE, JJ Cota Nieto, M Moreno Báez \& O AburtoOropeza. 2017. Vulnerability of spawning aggregations of a coastal marine fish to a small-scale fishery. Marine Biology 164: 157-184.

Fernández-Palacios H, MS Izquierdo, L Robaina, A Valencia, M Salhi \& JM Vergara. 1995. Effect of $n-3$ HUFA level in broodstock diets on egg quality of gilthead sea bream (Sparus aurata L.). Aquaculture 132: 325-337.

Fischer W, F Krupp, W Schneider, C Sommer, KE Carpenter \& VH Niem. 1995a. Guía FAO para la identificación de especies para los fines de la pesca. Pacífico Centro-Oriental. Vol. II. Vertebrados, Parte 1: 647-1200. FAO, Roma.

Fischer W, F Krupp, W Schneider, C Sommer, KE Carpenter \& VH Niem. 1995b. Guía FAO para la identificación de especies para los fines de la pesca. Pacífico Centro-Oriental. Vol. III. Vertebrados, Parte 2: 1201-1813. FAO, Roma.

Freitas MO, V Abilhoa, VJ Giglio, M Hostim-Silva, RL de Moura, RB Francini-Filho \& CV Minte-Vera. 2015. Diet and reproduction of the Goliath grouper, Epinephelus itajara (Actinopterygii-Perciformes: Serranidae), in Eastern Brazil. Acta Ichthyologica et Piscatoria 45(1): 1-11.

Fuiman LA \& CK Faulk. 2013. Batch spawning facilitates transfer of an essential nutrient from diet to eggs in a marine fish. Biology Letters 9: 20130593.<doi: 10.10981/ rsbl.2013.0593> 
Gómez CGO, LA Zapata, R Franke \& GE Ramos. 1999. Hábitos alimentarios de Epinephelus acanthistius y notas de otros peces serránidos capturados en el parque nacional natural de Gorgona, Pacífico colombiano. Boletín de Investigaciones Marinas y Costeras 28: 43-60.

Hacunda JS. 1981. Trophic relationships among demersal fishes in a coastal area of the Gulf of Maine. Fishery Bulletin 79(4): 775-788.

Humason GL. 1979. Animal tissue techniques, 650 pp. W.H. Freeman, San Francisco.

Hurlbert SH. 1978. The measurement of niche overlap and some relatives. Ecology 59(1): 67-77.

Hyslop EJ. 1980. Stomach contents analysis. A review of methods and their application. Journal of Fish Biology 17(4): 411-429.

Jalabert B. 2005. Particularities of reproduction and oogenesis in teleost fish compared to mammals. Reproduction Nutrition and Development 45: 261-279.

Jarvis ET, C Linardich \& CF Valle. 2010. Spawning-related movements of barred sand bass, Paralabrax nebulifer, in Southern California: Interpretations from two decades of histological tag and recapture data. Bulletin of the Southern California Academic of Sciences 109(3): 123-143.

Krebs CJ. 1999. Ecological methodology, 745 pp. Addison Wesley Longman, New York.

López-García J, AF Navia, PA Mejía-Falla \& A Rubio. 2012. Feeding habits and trophic ecology of Dasyatis longa (Elasmobranchii: Myliobatiformes): sexual, temporal and ontogenetic effects. Journal of Fish Biology 80: 1563-1579.

Love MS, D Busatto, J Stephens \& PA Gregory. 1996. Aspects of the life histories of the kelp bass, Paralabrax clathratus, and barred sand bass, P. nebulifer, from the southern California Bight. Fishery Bulletin 94: 472-481.

McKinzie MK, ET Jarvis \& CG Lowe. 2014. Fine-scale horizontal and vertical movement of barred sand bass, Paralabrax nebulifer, during spawning and non-spawning seasons. Fisheries Research 150: 66-75.

Mendoza-Carranza M \& JA Rosales-Casián. 2000. The feeding habits of spotted sand bass (Paralabrax maculatofasciatus) in Punta Banda Estuary, Ensenada, Baja California, Mexico. California Cooperative Oceanic Fisheries Investigations, Reports 41: 194-200.

Mendoza-Carranza M \& JA Rosales-Casián. 2002. Feeding ecology of juvenile kelp bass (Paralabrax clathratus) and barred sand bass (P. nebulifer) in Punta Banda Estuary, Baja California, Mexico. Bulletin of the Southern California of Academic Sciences 101(3): 103-117.

Miller DJ \& RN Lea. 1972. Guide to the coastal marine fishes of California, California Fish Bulletin 157: 1-235.

Mylonas CC, A Foster \& S Zanuy. 2010. Broodstock management and hormonal manipulations of fish reproduction. General and Comparative Endocrinology 165: 516-534.

Nakai T, M Sano \& H Kurokura. 2001. Feeding habits of the darkfin hind Cephalopholis urodeta (Serranidae) at Iriomote Island, southern Japan. Fisheries Science 67: 640-643.
Norton J, D McLain, R Brainard \& D Husby. 1985. The 1982-83 El Niño event off Baja and Alta California and its ocean climatic context. In: Wooster WS \& DL Fluharty (eds). El Niño north. Niño effects in the eastern Subarctic Pacific Ocean. Seattle WA (USA), pp. 44-72. Washington Sea Grant Program, University of Washington, Seattle.

Parrish R, CS Nelson \& A Bakun. 1981. Transport mechanism and reproductive success of fishes in the California Current. Biology and Oceanography 1(2): 175-203.

Pinkas L, M Oliphant \& ILK Iverson. 1971. Food habits of albacore, bluefin tuna, and bonito in California waters. California Fish and Game 152: 1-105.

Rachedi M, F Derbal \& H Kara. 2018. Feeding habits of the comber Serranus cabrilla (Linnaeus, 1758) (Teleostei: Serranidae) from the Gulf of Annaba (Eastern coast of Algeria). Cahiers de Biologie Marine 59: 149-158.

Roberts D, E DeMartini \& K Plummer. 1984. The feeding habits of juvenile-small adult barred sand bass (Paralabrax nebulifer) in nearshore waters off northern San Diego County. California Cooperative Oceanic Fisheries Investigations Report 25: 105-111.

Robertson DR \& GR Allen. 2015. Peces costeros del Pacífico Oriental Tropical: Sistema de Información en línea. Versión 2.0 Instituto Smithsonian de Investigaciones Tropicales, Balboa. $<$ https://biogeodb.stri.si.edu/sftep/es/pages $>$

SAGARPA. 2016. Información estadística por especie y entidad. $<$ http://www.conapesca.sagarpa.gob.mx/wb/cona/ consulta_especifica_por_produccion>

Smith LS. 1989. Digestive functions in teleost fishes. In: Halver JE (ed). Fish nutrition, pp. 331-421. Academic Press, London.

Smith-Vaniz B, R Robertson, A Dominici-Arosemena, H Molina, E Salas \& AG Guzmán-Mora. 2010. Paralabrax nebulifer. The IUCN Red List of Threatened Species 2010:c.T183861A8190471.<http://dx.doi.org/10.2305/ IUCN.UK.2010-3.RLTS.T838661A8190471>

Torres-Villegas JR, RI Ochoa-Báez, L Perezgómez \& G García-Melgar. 2007. Estimaciones de atresia mayor en la temporada reproductiva 1999-2000 en la sardina monterrey (Sardinops sagax) en Bahía Magdalena, México. Revista de Biología Marina y Oceanografía 42(3): 299-310.

Torrisen OJ \& R Christiansen. 1995. Requirements for carotenoids in fish diets. Journal of Applied Ichthyology 11: 225-230.

Vasilik M. 2016. An estimation of the diet of the species Serranus scriba (Linnaeus, 1758) in the Area of Nisiopi, in South-West Lesbos. Journal of Environmental Science and Engineering A 5: 593-600.

Ward TM, LJ McLeay, WF Dimmlich, PJ Rogers, S McClatchie, R Matthews, J Kämpf \& PD Van Ruth. 2006. Pelagic ecology of a northern boundary current systems: effects of upwelling on the production and distribution of sardine (Sardinops sagax), anchovy (Engraulis australis) and southern bluefin tuna (Thunnus maccoyi) in the Great Australian Bight. Fisheries Oceanography 15(3): 191-207. 
Wolff CA. 1984. Identification and estimation of size from the beaks of 18 species of cephalopods from the Pacific Ocean. NOAA Technical Reports National Marine Fisheries Service 17: 1-50.

Yamahira K. 2004. How do multiple environmental cycles in combination determine reproductive timing in marine organisms? A model and test. Functional Ecology 18: 4-15.
Zaytsev O, R Cervantes-Duarte, O Montante \& A Gallegos-García. 2003. Coastal upwelling activity on the Pacific Shelf of the Baja California Peninsula. Journal of Oceanography 59: 489-502.

Zaytsev O, A Trasviña-Castro, J Linero-Cueto, G GaxiolaCastro \& J Cepeda-Morales. 2014. Oceanographic conditions over the continental shelf off Magdalena Bay (Mexico). Ciencias Marinas 40(2): 89-112.

Recibido el 15 de mayo 2020 y aceptado el 25 de febrero de 2021

Editor asociado: Mauricio Landaeta D. 